\title{
Hyperuricemia and Its Correlation with Target Organ Damage and Electrocardiographic Changes in Newly Diagnosed Adult Nigerian Hypertensive Patients
}

\author{
Abidemi Jude Fasae ${ }^{1}$, Olusegun Adesola Busari ${ }^{1, ~ *, ~ R o t i m i ~ O l u y o m b o ' ~}{ }^{1}$, Musa Yusuf ${ }^{1}$, \\ Oladipo George Opadijo ${ }^{2}$, Ayodele Babatunde Omotoso ${ }^{3}$ \\ ${ }^{1}$ Department of Internal Medicine, Federal Teaching Hospital, Ido-Ekiti, Nigeria \\ ${ }^{2}$ Department of Internal Medicine, Ladoke Akintola University Teaching Hospital, Ogbomoso, Nigeria \\ ${ }^{3}$ Department of Internal Medicine, University of Ilorin Teaching Hospital, Ilorin, Nigeria
}

Email address:

olubusari@yahoo.com (O. A. Busari)

${ }^{*}$ Corresponding author

\section{To cite this article:}

Abidemi Jude Fasae, Olusegun Adesola Busari, Rotimi Oluyombo, Musa Yusuf, Oladipo George Opadijo, Ayodele Babatunde Omotoso. Hyperuricemia and Its Correlation with Target Organ Damage and Electrocardiographic Changes in Newly Diagnosed Adult Nigerian Hypertensive Patients. Clinical Medicine Research. Vol. 7, No. 1, 2018, pp. 1-7. doi: 10.11648/j.cmr.20180701.11

Received: March 10, 2017; Accepted: April 10, 2017; Published: January 26, 2018

\begin{abstract}
The objective of the study was to determine the prevalence of Hyperuricemia and evaluate its correlation with target organ damage and electrocardiographic changes in newly diagnosed adult Nigerian hypertensive patients. It was a cross sectional study done at the University of Ilorin Teaching Hospital, Ilorin, Nigeria. 150 untreated newly diagnosed hypertensive patients 18 years and above and 115 age and sex-matched normotensive individuals were recruited into the study. Data obtained was analyzed using Epi-Info version 6.04 and Statistical Package for Social Sciences (SPSS) version 14 computer software packages. The prevalence of Hyperuricemia was $36.7 \%$ and $17.4 \%$ in hypertensive patients and normotensive controls respectively. Mean serum UA in hypertensive patients and normotensive controls was $0.4 \pm 0.1 \mathrm{mmol} / 1$ and $0.3 \pm 0.1 \mathrm{mmol} / 1$ respectively $(\mathrm{p}<0.0001)$. There was an association between Hyperuricemia and left ventricular hypertrophy $\left(x^{2}=23.97, p<0.0001\right)$. The study showed that Hyperuricemia is prevalent in adult Nigerians with newly diagnosed hypertension. Hyperuricemia was associated with left ventricular hypertrophy which is common target organ damage and confers an increased risk of cardiovascular events in systemic hypertension.
\end{abstract}

Keywords: Hyperuricemia, Target Organ Damage, Electrocardiographic Changes, Hypertensive Nigerians

\section{Introduction}

Systemic hypertension (HT) is a common disease globally, with populations of African descent being most prone to its complications [1-5]. In 2010, HT was the commonest of the three leading risk factors for global disease burden [6]. The reason for the enormous burden of HT has been reported in numerous studies, showing that it is strongly associated with overall cardiovascular risk [6-8]. HT contributes to both cardiovascular and cerebrovascular endpoints, including heart failure (HF), myocardial infarction (MI) and stroke and it accounts for $16.5 \%$ of all deaths including $51 \%$ of deaths due to strokes and $45 \%$ of deaths due to coronary artery disease
(CAD) [7, 8]. The prevalence of HT has been increasing globally and it has been estimated that it will increase to $29.2 \%$ by 2025 [2]. In Nigeria, studies have reported prevalence varying from $12 \%$ to $36.6 \%$ [9-13]. HT is implicated in $35 \%$ of all atherosclerotic cardiovascular events, including over $40 \%$ of all cases of HF [14-17]. In the US, $33.0 \%$ of adults aged 20 years and older have HT. African American adults have among the highest prevalence of HT (44\%) in the world [18]. The Framingham and other epidemiological surveys as well as experimental studies have shown that hyperuricemia (HU) significantly increases the risk for cardiovascular disease 
and complications $[17,19,20]$.

Some studies done in Nigeria and other developing countries have shown that the prevalence of HU can be high in hypertensive patients in developing countries, thereby underscoring its importance as a cardiovascular risk factor $[21,22]$. There are a few reports about HU in untreated hypertensive adult Nigerians [21, 23]. Abengowe [23] investigated the relationship between HU, untreated HT and alcohol consumption in Nigerian men and excluded women. Also, Adedeji and Onitiri [22] studied HU and serum lipid abnormalities in Nigerian hypertensive patients but included those who were on antihypertensive drugs.

The objective of the study was to determine the prevalence of $\mathrm{HU}$ and evaluate its correlation with target organ damage (TOD) and electrocardiographic (ECG) changes in newly diagnosed adult Nigerian hypertensive patients.

\section{Materials and Methods}

\subsection{Study Design and Study Site}

The study was a cross sectional study done at the General Out-patient Department (GOPD), Medical Out-patient Department (MOPD) and Emergency Room (ER) of the University of Ilorin Teaching Hospital, Ilorin, in the North Central geopolitical zone of Nigeria between May 2007 and October 2007.

\subsection{Ethical Considerations}

The study protocol was approved by the Ethics and Research Committee of the hospital, and both oral and written consent was obtained from all the participants.

\subsection{Study Participants}

One hundred and fifty (150) untreated newly diagnosed hypertensive patients 18 years and above and one hundred and fifteen (115) age and sex-matched normotensive individuals were recruited into the study. Excluded from the study were participants with significant history of alcohol ingestion; those on drugs such as lipid lowering drugs, uricosuric agents, antituberculous and antiretroviral drugs; cancer patients taking or not taking cytotoxic drugs; patients with renal impairment and diabetes mellitus (DM).

\subsection{Clinical Evaluation, Measurements and Definitions}

All participants had a detailed history and a thorough physical examination, including anthropometry.

\subsubsection{Anthropometry}

Each participant's height in meters was determined using Marsden's Stadiometer with maximum height of 2 meters. The measurement was performed to the nearest $0.1 \mathrm{~cm}$. Weight in kilogram was determined using Detecto electrical column scale; model CN 20 with $180 \mathrm{~kg}$ capacity. The body weight was measured to the nearest $0.1 \mathrm{~kg}$ and the body mass index (BMI) $\left(\mathrm{Kg} / \mathrm{m}^{2}\right)$ [24] was determined by dividing the weight $(\mathrm{Kg})$ by the square of the height $(\mathrm{m})$. The waist circumference (WC) $(\mathrm{cm})$ was measured with a tape at the umbilical level on the bare abdomen, and the hip circumference $(\mathrm{HC})(\mathrm{cm})$ measured at the external margins of the anterior superior iliac spines and waist/hip (WHR) ratio was determined [25]. Abdominal/central obesity was defined as WHR: $>1.0$ (men), $>0.9$ (women), WC: $>102 \mathrm{~cm}(40$ in) $>88 \mathrm{~cm}$ (35 in) in women. Overweight and obesity were also defined as: $\mathrm{BMI} \geq 25 \mathrm{~kg} / \mathrm{m}^{2}$ and $\geq 30 \mathrm{~kg} / \mathrm{m}^{2}$ respectively.

\subsubsection{Blood Pressure Measurement}

Blood pressure was measured using mercury column sphygmomanometer (Accosson) and a cuff of appropriate size $(25 \mathrm{~cm} \times 12 \mathrm{~cm})$. A standardized protocol was followed, in which systolic (SBP) and diastolic blood pressure (DBP) was measured on the right arm after at least 5 min of rest. Two consecutive measurements were obtained 5 minutes apart and the average was obtained. Phase I Korotkoff sound was used for SBP and phase V for the DBP. HT was defined as SBP $\geq 140 \mathrm{mmHg}$ and/or DBP $\geq 90 \mathrm{mmHg}$, or use of antihypertensive drugs [26-29].

\subsubsection{Precordial and Arterial Wall Examination}

The precordium was examined for the location and character of the cardiacapex, presence of a fourth heart sound (S4), and intensity of the aortic component of the second heart sound (A2). The radial pulse was examined for arterial wall thickening (cord-like artery on palpation) [30].

\subsubsection{Funduscopy}

Each participant had funduscopic examination done by the principal investigator using Keeler $^{\circledR}$ ophthalmoscope. The retina was examined for arteriovenous nicking, copper/silver wiring of the retina vessels, cotton wool exudates / flameshaped hemorrhages and papilledema. Hypertensive retinopathy was graded according to the Keith-WagenerBarker classification [31] into:

Grade 1: Copper/Silver wiring of retinal arteries

Grade 2: Grade 1 plus arteriovenous nicking

Grade 3: Grade 2 plus cotton wool exudates / flameshaped hemorrhages

Grade 4: Grade 3 plus papilledema

\subsubsection{Electrocardiography}

All participants had a 12-lead resting electrocardiogram (ECG) done in supine position using Schiller Cardiovit AT-2 machine at $25 \mathrm{~mm} / \mathrm{s}$ speed and sensitivity of $10 \mathrm{~mm} / \mathrm{mV}$ in the hospital, and was interpreted by the principal investigator and subsequently vetted by a cardiologist. The ECG tracings were examined for left atrial enlargement (LAE), left ventricular hypertrophy (LVH) with or without strain pattern / ischemia, infarction, heart blocks, arrhythmias and resultant QRS axis. LAE and LVH were determined using Araoye criteria $[32,33]$ which state thus:

1. $\mathrm{LAE}=\mathrm{P}$ terminal force in lead $\mathrm{V}_{1}>1 \mathrm{~mm}$ or $\mathrm{P}$ wave notching $>40 \mathrm{msec}$ or a "Macruz" index [34] $>3$.

2. $\mathrm{LVH}=(1) \mathrm{SV}_{2}+\mathrm{RV}_{6}>4.0 \mathrm{mV}$ (Male) $;>3.5 \mathrm{mV}$ (Female)

3. Flat or inverted $\mathrm{T}$ wave ("Strain pattern") in $\mathrm{V}_{5}$ or $\mathrm{V}_{6}$

4. $\mathrm{R}_{1}$ amplitude $>1.2 \mathrm{mV}$ 


\subsubsection{Serum Uric Acid Measurement}

Serum uric acid level was estimated at the Chemical Pathology laboratory of the hospital using Fe (III) reduction direct method with Intraseries and Interseries Variation Coefficient of $2.09 \%$ and $2.38 \%$ respectively and Recovery of $96.6 \%$. Hyperuricemia was defined as serum UA level $>$ $0.42 \mathrm{~m} \mathrm{~mol} / \mathrm{L}$ for males and $>0.36 \mathrm{~m} \mathrm{~mol} / \mathrm{L}$ for females.

\subsubsection{Other Laboratory Measurements}

Venous blood samples were collected from the study participants for fasting serum lipids assay, serum electrolytes panel and serum urea (BUN) and creatinine, fasting blood glucose (FBG) and others.

\subsection{Data Analysis}

Data obtained was analyzed using Epi-Info version 6.04 and Statistical Package for Social Sciences (SPSS) version 14 computer software packages. Results for continuous variables were expressed as mean $\pm \mathrm{SD}$ and proportions as percentages. The Chi square $\left(\mathrm{x}^{2}\right)$, with Yate's correction where applicable, was used to determine the statistical significance of categorical variables between the different groups. Student's t-test was used to assess the significance between means of two groups. Pearson's correlation coefficient was used to assess the correlation between measured variables. Cross-tabulation was performed to investigate the associations of different variables with serum uric acid. $\mathrm{P}$ value $\leq 0.05$ was considered statistically significant.

\section{Results}

Fifty two $(34.7 \%)$ of the 150 newly diagnosed hypertensive patients were males while 98 (65.3\%) were females, with age range of 19-85 years and a mean age of $50.4 \pm 12.3$ years. The mean age and range of the normotensive controls are shown in Table 1. No statistical difference was observed in the mean ages of the patients and the controls $(p=0.67)$. Table 1 shows the other sociodemographic characteristics of the patients and controls. Mean SBP and DBP of the hypertensive patients are $175 \pm 24.0 \mathrm{mmHg}$ and $106 \pm 16.4 \mathrm{mmHg}$ respectively; and $119.8 \pm 9.1 \mathrm{mmHg}$ and $78.2 \pm 8.3 \mathrm{mmHg}$ respectively for normotensive controls (SBP, $\mathrm{p}<0.0001$; DBP, $\mathrm{P}<0.001$ ). Other clinical characteristics of the hypertensive patients and the normotensive controls are presented in Table 2.

The prevalence of $\mathrm{HU}$ was $36.7 \%$ and $17.4 \%$ in hypertensive patients and normotensive controls respectively. Mean serum UA in hypertensive patients and normotensive controls was $0.4 \pm 0.1 \mathrm{mmol} / 1$ and $0.3 \pm 0.1 \mathrm{mmol} / 1$ respectively $(\mathrm{p}<0.0001)$. In the hypertensive patients, males had higher mean serum UA than females $(0.4 \pm 0.1 \mathrm{mmol} / 1$ vs $0.3 \pm 0.1 \mathrm{mmol} / 1, \mathrm{p}=0.01)$. The mean serum $\mathrm{TC}$ in hypertensive patients was $5.1 \pm 1.1 \mathrm{mmol} / 1$ and in normotensive controls $3.6 \pm 1.5 \mathrm{mmol} / 1 \quad(\mathrm{p}<0.001)$. Table 3 shows the other biochemical characteristics of the patients and the controls. One hundred and twenty nine $(86.1 \%)$ of hypertensive patients had abnormal ECG compared to $18(16.5 \%)$ in the normotensive controls $(\mathrm{p}<0.0001)$. Among the hypertensive patients; $28.7 \%$ had LVH alone, $21.3 \%$ had LAE alone, and $27.3 \%$ had both LVH and LAE. Other ECG findings are presented in Table 4.

There was an association between HU and LVH $\left(\mathrm{x}^{2}=23.97\right.$, $\mathrm{p}<0.0001)$. Table 5 presents the mean serum UA in various ECG characteristics. As shown in Table 6, mean serum UA was higher in hypertensive patients with LVH than those with normal ECG, however, not statistically significant $(0.4 \pm 0.1 \mathrm{mmol} / 1$ vs $0.3 \pm 0.1 \mathrm{mmol} / 1, \mathrm{p}=0.2)$. Seventeen percent of hypertensive patients had HU (mean serum $\mathrm{UA}=0.5 \pm 0.1 \mathrm{mmol} / \mathrm{l}$ ) with $\mathrm{LVH}$ while $40 \%$ of hypertensive patients had LVH with normal serum UA (mean serum $\mathrm{UA}=0.3 \pm 0.1 \mathrm{mmol} / \mathrm{l}$ ) $\mathrm{p}<0.001$ (Table 6).

\section{Discussion}

In this study, more females than males were examined in both hypertensive patients and normotensive controls with male: female ratio of $1: 1.9(p<0.0001)$ and $1: 1.4(p=0.02)$ respectively. This might be due to the fact that females tend to seek medical attention earlier and more frequently than males. The prevalence of HU in hypertensive patients was $36.7 \%$. This is lower than the $55 \%$ and $52.9 \%$ reported by Obeka (21) and Murugan et al [35] respectively, and higher than figures $(26 \%-33 \%)$ reported in studies on Caucasians $[36,37]$. The potential mechanisms behind the link between HU and HT, cardiovascular and renal abnormalities include nitric oxide and renin-angiotensin-aldosterone system (RAAS) pathways [38, 39]. HU may cause endothelial cell dysfunction via nitric oxide synthetase [40-42] and stimulate proliferation of vascular smooth muscle cell $[43,44]$. It may also directly stimulate the renin-angiotensin-aldosterone system [45, 46]. Uric acid may also cause renal afferent arteriolopathy and tubulointerstitial disease, leading to chronic kidney disease and HT [47].

There was a significant association between serum UA and LVH $(p<0.001)$, presence of accentuated A2 $(p<0.001)$, S4 $(p=0.025)$ and displaced apex beat $(p=0.005)$. It was observed that the mean serum UA was higher, though not significant, in hypertensive patients with these signs of target organ damage (TOD) than in those without these signs. These findings corroborate those reported by Viazzi et al [48] that the association between serum UA and early hypertensive damage suggests that mild $\mathrm{HU}$ might be a marker of incipient cardiovascular involvement and may be associated with increased morbidity in hypertensive patients. Also, in this study, the association between serum UA and LVH was stronger in males $(p=0.02)$ than in females $(\mathrm{p}=0.04)$. This is in contrast to what was found by Viazzi et al [48]. This might be due to higher serum UA and greater left ventricular mass in males than in females [49], especially people of African descent [50].

Target organ damage (LVH and accentuated A2) was found more frequently in hypertensive patients with higher levels of serum TC and LDL-c than their counterparts with 
normal levels. This finding is in consonance with that reported by Giuseppe et al [51] and Mule et al [52]. The association of these metabolic parameters with cardiac hypertrophy (LVH) might be explained by insulin resistance and the accompanying hyperinsulinemia, which are regarded as the pathophysiological key features underlying metabolic syndrome $[53,54]$. Trophic effect of insulin on myocardial tissue has been demonstrated in cell cultures and animal models [55], and may be mediated, at least in part by the insulin-like growth factor [56]. In addition, insulin may affect left ventricular mass indirectly by increasing sodium retention or endothelin-1 level, or by inducing sympathetic activation [57].

\section{Conclusion}

The study reveals that HU is prevalent in adult Nigerians with newly diagnosed HT. HU was associated with LVH which is common target organ damage and confers an increased risk of cardiovascular events in HT. Thus, the study recommends a routine baseline evaluation of serum UA in newly diagnosed hypertensive patients and periodic assessment in patients on antihypertensive drugs.

Table 1. Sociodemographic characteristics of hypertensive patients and normotensive controls.

\begin{tabular}{|c|c|c|c|c|}
\hline & Hypertensive patients & Normotensive controls & $X^{2}$ & $\mathbf{P}$ \\
\hline \multicolumn{5}{|l|}{ Age } \\
\hline Mean & $50.4 \pm 12.3$ & $50.7 \pm 12.7$ & & \\
\hline Range & $19-85$ & $23-80$ & & \\
\hline \multicolumn{5}{|l|}{ Sex } \\
\hline Male & $52(34.7)$ & $49(42.6)$ & & \\
\hline Female & $98(65.3)$ & $66(57.4)$ & & \\
\hline \multicolumn{5}{|l|}{ Marital Status } \\
\hline Married & $78(52)$ & $63(54.8)$ & 0.2 & 0.004 \\
\hline Widowed & $40(26.7)$ & $22(19.1)$ & 2.06 & $<0.001$ \\
\hline Divorced & $20(13.3)$ & $13(11.3)$ & 0.25 & $<0.001$ \\
\hline \multicolumn{5}{|l|}{ Education } \\
\hline Nil & $34(22.6)$ & $25(21.7)$ & 0.03 & 0.86 \\
\hline Primary & $46(30.7)$ & $21(18.3)$ & 5.30 & 0.02 \\
\hline Secondary & $41(27.3)$ & $13(11.3)$ & 10.31 & 0.001 \\
\hline
\end{tabular}

Table 2. Clinical characteristics of hypertensive patients and normotensive controls.

\begin{tabular}{|c|c|c|c|c|c|c|}
\hline Normotensive controls & Hypertensives patients & Variables & Normo Hypert & Males Females & Males Females & \\
\hline & $(n=115)$ & $(n=150) p$ value & $(n=49)$ & $(n=66) p$ value & $(n=52)$ & $(n=98) p$ value \\
\hline Age (yrs) & $50.7(12.7)$ & $50.4(12.3) 0.8$ & $50.8(15.8)$ & $51.4(16.3) 0.81$ & $51.0(12.7)$ & $50.1(12.1) 0.67$ \\
\hline BMI $\left(\mathrm{Kg} / \mathrm{m}^{2}\right)$ & $23.3(4.2)$ & $27.2(15.8)<0.0001 *$ & $23.2(4.1)$ & $23.4(4.4) 0.76$ & $25.6(5.5)$ & $27.9(5.7) 0.02 *$ \\
\hline $\mathrm{SBP}(\mathrm{mmHg})$ & $119.8(9.0)$ & $175.2(24.0)<0.0001^{*}$ & $118.4(9.9)$ & $120.6(9.8) 0.24$ & $177.2(26.9)$ & $174.1(22.4) 0.45$ \\
\hline $\mathrm{DBP}(\mathrm{mmHg})$ & $78.3(8.3)$ & $106.0(16.4)<0.0001 *$ & $77.8(9.4)$ & $77.6(7.5) 0.90$ & $108.8(16.8)$ & $104.5(16.1) 0.13$ \\
\hline $\mathrm{WC}(\mathrm{cm})$ & $83.1(12.3)$ & $93.4(12.9)<0.0001 *$ & $83.0(12.0)$ & $83.2(12.7) 0.93$ & $92.3(14.9)$ & $94.2(11.6) 0.37$ \\
\hline WHR & $0.96(0.1)$ & $0.98(0.1) 0.06$ & $0.97(0.1)$ & $0.94(0.1) 0.002 *$ & $1.01(0.1)$ & $0.96(0.1) 0.0001^{*}$ \\
\hline LMB & $1.7 \%$ & $53.3 \%<0.0001^{*}$ & $14.3 \%$ & $3.0 \% 0.06$ & $73.1 \%$ & $42.9 \% 0.0004 *$ \\
\hline $\mathrm{A} 2$ & $4.3 \%$ & $66.0 \%<0.0001^{*}$ & $14.3 \%$ & $7.6 \% 0.24$ & $63.5 \%$ & $67.3 \% 0.63$ \\
\hline S4 & $1.7 \%$ & $25.3 \%<0.0001^{*}$ & $2.0 \%$ & $1.5 \%$ & $19.2 \%$ & $28.6 \% 0.21$ \\
\hline Fundi+ & $4.4 \%$ & $38.0 \%<0.0001^{*}$ & $6.1 \%$ & $3.0 \% 0.73$ & $51.9 \%$ & $29.6 \% 0.007 *$ \\
\hline Abloc & $0.9 \%$ & $15.3 \% 0.0001 *$ & $1.5 \%$ & -- & $25.0 \%$ & $10.2 \% 0.02 *$ \\
\hline Abch & $1.7 \%$ & $28.7 \%<0.0001^{*}$ & $3.0 \%$ & -- & $23.1 \%$ & $31.6 \% 0.27$ \\
\hline
\end{tabular}

Data are presented as mean (SD); ${ }^{*}$ Differences are statistically significant; Art wall = Arterial wall -thickened;

$\mathrm{LMB}=$ Locomotor brachialis - present; A2 = Aortic component of the second heart sound - loud;

S4 = Fourth heart sound - present; Abloc = Apex beat location - displaced; Abch = Apex beat character - Heaving;

$+\geq$ Grade 2 hypertensive retinopathy; BMI - body mass index; SBP - Systolic blood pressure; DBP - diastolic blood pressure;

WC - waist circumference; WHR - Waist - hip ratio. Norm - Normotensives, Hypert - hypertensives

Table 3. Biochemical characteristics of hypertensive patients and normotensive controls.

\begin{tabular}{|c|c|c|c|c|c|c|}
\hline Normotensive controls & Hypertensives patients & Variables & Normo Hypert & Males Females & Males Females & \\
\hline & $(n=115)$ & $(n=150) p$ value & $(n=49)$ & $(n=66) p$ value & $(n=52)$ & $(n=98) p$ value \\
\hline $\mathrm{UA}(\mathrm{mmol} / \mathrm{l})$ & $0.3(0.1)$ & $0.4(0.1)<0.0001^{*}$ & $0.3(0.2)$ & $0.3(0.1) 0.004^{*}$ & $0.4(0.1)$ & $0.3(0.1) 0.01 *$ \\
\hline $\mathrm{FBG}(\mathrm{mmol} / \mathrm{l})$ & $4.5(1.2)$ & $4.2(0.9) 0.13$ & $4.7(1.0)$ & $4.4(1.4) 0.29$ & $4.4(0.7)$ & $4.2(0.9) 0.39$ \\
\hline $\mathrm{TC}(\mathrm{mmol} / \mathrm{l})$ & $3.6(1.5)$ & $5.1(1.1)<0.0001 *$ & $3.6(1.4)$ & $3.6(1.6) 0.88$ & $5.1(1.0)$ & $5.1(1.2) 0.92$ \\
\hline LDL-c(mmol/1) & $2.2(1.0)$ & $3.1(1.1)<0.0001^{*}$ & $2.2(0.9)$ & $2.2(1.0) 0.90$ & $3.1(1.1)$ & $3.2(1.2) 0.71$ \\
\hline HDL-c (mmol/1) & $1.4(0.4)$ & $1.5(0.6) 0.88$ & $1.4(0.4)$ & $1.5(0.4) 0.09$ & $1.4(0.5)$ & $1.5(0.6) 0.88$ \\
\hline $\mathrm{TG}(\mathrm{mmol} / \mathrm{l})$ & $1.1(0.5)$ & $1.2(0.5) 0.10$ & $1.4(0.8)$ & $1.4(0.9) 0.68$ & $1.3(0.6)$ & $1.2(0.5) 0.56$ \\
\hline
\end{tabular}




\begin{tabular}{|c|c|c|c|c|c|c|}
\hline Normotensive controls & Hypertensives patients & Variables & Normo Hypert & Males Females & Males Females & \\
\hline & $(n=115)$ & $(n=150) p$ value & $(n=49)$ & $(n=66) p$ value & $(n=52)$ & $(n=98) p$ value \\
\hline TC/HDC-c & $1.9(1.1)$ & $2.7(2.2) 0.002 *$ & $1.8(1.2)$ & $1.6(0.9) 0.24$ & $2.4(1.4)$ & $2.8(2.5) 0.36$ \\
\hline $\mathrm{BUN}(\mathrm{mmol} / \mathrm{l})$ & $3.7(1.5)$ & $5.3(1.7)<0.0001^{*}$ & $3.9(1.5)$ & $3.7(1.6) 0.45$ & $5.3(1.7)$ & $4.8(1.0) 0.16$ \\
\hline $\mathrm{Cr}(\mu \mathrm{mol} / \mathrm{l})$ & $94.2(19.0)$ & $95.4(15.3) 0.75$ & $96.8(13.8)$ & $92.8(21.9) 0.36$ & $94.7(15.3)$ & $90.3(22.7) 0.31$ \\
\hline
\end{tabular}

Table 4. Electrocardiographic characteristics of hypertensive patients and normotensive controls.

\begin{tabular}{llll}
\hline & Hypertensive patients & Normotensive controls & p value \\
\hline & $(\mathrm{n}=150)$ & $(\mathrm{n}=115)$ & $<0.0001$ \\
Normal ECG & $28(18.7)$ & $99(86.1)$ & $<0.0001$ \\
LAE alone & $40(21.3)$ & $7(6.1)$ & $<0.0001$ \\
LVH alone & $43(28.7)$ & $3(2.6)$ & $<0.0001$ \\
LAE + LVH & $41(27.3)$ & $6(5.2)$ & - \\
Heart blocks & $4(2.7)$ & - & - \\
Atrial fibrillation & $1(1.3)$ & - & \\
Other arrhythmias & - & & \\
\hline
\end{tabular}

Table 5. Mean serum uric acid and electrocardiographic characteristics in hypertensive patients.

\begin{tabular}{ll}
\hline Variables & Mean SUA \\
\hline Normal ECG & $0.30(0.1)$ \\
LVH & $0.4(0.1)$ \\
LAE & $0.3(0.1)$ \\
Heart blocks & $0.3(0.1)$ \\
*Arrhythmia & $0.4(0.1)$ \\
\hline
\end{tabular}

Values are expressed as Mean (SD). *Only two patients had arrhythmia (Atrial fibrillation)

Table 6. Comparison of means serum uric acid in left ventricular hypertrophy, normal electrocardiogram and other electrocardiographic abnormalities.

\begin{tabular}{lllll}
\hline & N & Mean (SD) & t & p value \\
\hline LVH & 83 & $0.4(0.1)$ & & \\
Other ECG & 38 & $0.3(0.1)$ & 1.2 & 0.32 \\
abnormalities & & & & \\
LVH & 83 & $0.4(0.1)$ & & \\
Normal ECG & 29 & $0.3(0.1)$ & 0.6 & 0.20 \\
\hline
\end{tabular}

Table 7. Mean serum uric acid in hypertensive target organ damage.

\begin{tabular}{lllll}
\hline Variables & N & Mean serum UA & t & p value \\
\hline Loud A2 & 99 & $0.4(0.1)$ & & \\
Normal A2 & 51 & $0.4(0.1)$ & -0.19 & 0.84 \\
Present S4 & 38 & $0.3(0.1)$ & & \\
Absent S4 & 112 & $0.4(0.1)$ & 0.49 & 0.63 \\
Hyper Retin. & 57 & $0.4(0.1)$ & & \\
Normal Fund. & 93 & $0.4(0.1)$ & -0.04 & 0.97 \\
Displaced AB & 23 & $0.4(0.1)$ & & \\
Normal AB & 127 & $0.4(0.1)$ & -0.38 & 0.71 \\
Heaving AB & 107 & $0.3(0.1)$ & 0.74 & 0.60 \\
\hline
\end{tabular}

$\mathrm{p}<0.05$; Hyper Retin=Hypertensive Retinopathy; $\mathrm{AB}=\mathrm{Apex} \quad$ Beat; Fund=Fundus

\section{References}

[1] Kearney PM, Whelton M, Reynolds K, Whelton PK, He J. Worldwide prevalence of hypertension: A systematic review. J Hypertens 2004; 22(1):11-9.

[2] Kearney PM, Whelton M, Reynolds K, Munter P, Whelton PK, He J. Global burden of hypertension: Analysis of worldwide data. Lancet 2005; 365 (9455):217-23.
[3] Rotimi CN. Hypertension in Blacks. Am J Hypertens 1997; 10: 804-12.

[4] Isezuo SA. Systemic hypertension in Blacks. An overview of current concepts of pathogenesis and management. Nig Postg Med Journal. 2003; 10(3):144-153.

[5] Phyllis A. Initial management of hypertension. N Eng J Med. 2003; 348: 610-617.

[6] Epidemiology of Cardiovascular Disease in the 21st Century: Updated Numbers and Updated Facts. Journal of Cardiovascular Disease. 2013; 1(1): 2326-3121.

[7] Lim SS, Vos T, Flaxman AD, Danaei G, Shibuya K, AdairRohani H, et al. A comparative risk assessment of burden of disease and injury attributable to 67 risk factors and risk factor clusters in 21 regions, 1990-2010: A systematic analysis for the Global Burden of Disease Study 2010. Lancet 2012; 380(9859):2224-60.

[8] Santulli G. Coronary heart disease risk factors and mortality. JAMA. 2012; 307(11): 1137-1138.

[9] Akinkugbe OO. The epidemiology of hypertension in Africa. In: Akinkugbe, ed. Cardiovascular diseases in Africa. CibaGeigy. 1976; 91-10.

[10] Adedoyin RA, Mbada CE, Balogun MO, Martins T, Adebayo RA, Akintomide A, et al. Prevalence and pattern of hypertension in a semiurban community in Nigeria. Eur $\mathbf{J}$ Cardiovasc Prev Rehabil. 2008; 15(6):683-7.

[11] Ofuya Z. The incidence of hypertension among a select population of adults in the Niger Delta region of Nigeria. Southeast Asian J Trop Med Public Health 2007; 38 (5): 947-9.

[12] Akinkungbe OO, Oladipo B. Current epidemiology of hypertension in Nigeria. Archives of Ibadan Medicine 2001; 1(1): 4-8.

[13] Oladapo OO, Salako L, Sodiq O, Shoyinka K, Adedapo K, Falase AO. A prevalence of cardiometabolic risk factors among a rural Yoruba south-western Nigerian population: a population-based survey. Cardiovasc J Afr. 2010; 21(1):2631.

[14] Kannel WB. Blood pressure as a cardiovascular risk factor. JAMA1996; 275:157-160.

[15] Levi D, Larson MG, Vassan RS, Kannel WB. The progression from hypertension to congestive heart failure. JAMA. 1996; 275: 1557-15562. 
[16] Falase AO, Ayeni O, Sekoni GA, Odia OJ. Heart failure in Nigerian hypertensives. Afri J Med Sci. 1983; 12:7-15.

[17] Wilson PW. Established risk factors and coronary artery disease: The Framingham study. Am J Hypertens 1994; 7: 7S.

[18] Go AS, Mozaffarian D, Roger VL, Benjamin EJ, Berry JD, Borden WB, et al. American Heart Association Statistics C and Stroke Statistics S. Heart disease and stroke statistics-2013 update: A report from the American Heart Association. Circulation 2013; 12 7(1):e6-e245.

[19] The Hypertension Detection and Follow-up program Cooperative group: Findings for stepped care and referred care participants in the HDFP, stratified by risk factors. Prev Med. 1985; 14: 312-335.

[20] Heyden S, Bohrani NO, Tyroler HA. The relationship of weight changes in blood pressure, serum uric acid, cholesterol and glucose in the treatment of hypertension. J Chro Dis. 1985; $38: 281-288$

[21] Obeka N C. Serum uric acid and lipid profile in hypertensive adult Nigerians. Dissertation for the West African College of Physicians. April 2004.

[22] Adedeji OO, Onitiri AC. Plasma lipids and Nigerian hypertensives. Afri J med Sci. 1990; 19: 281-284.

[23] Abengowe, CU. Serum uric acid values, hypertension and alcohol consumption in Nigerian men. Trop Card 1987; 13(51): 100-112.

[24] WHO Working group. Use and interpretation of anthropometric indications of nutritional status. Bulletin of the World health Organization.1986; 64: 929-941.

[25] Ukoh VA, Oforofuol AO. A comparative study of body mass index and waist-hip ratio in relation to serum lipids amongst hypertensive and normotensive Nigerians. Trop Card. 1999; 25 (97):7-10.

[26] The Sixth Report of the Joint National Committee on Prevention, Detection, Evaluation and Treatment of High Blood Pressure. Arch Int Med. 1997; 157: 2413-4.

[27] Chobanian AV, Bakris GL, Black HR, Cushman WC, Green LA, Izzo JL Jr, et al. The Seventh Report of the Joint National Committee on Prevention, Detection, Evaluation and Treatment of High Blood Pressure: JNC 7 Report. JAMA 2003; 289: 2560-72.

[28] World Health Organization (WHO)/ International Society of Hypertension (ISH) statement on management of hypertension. J Hypertens 2003; 32: 1983-92.

[29] Friedewald WT, Levy RL, Fredrickson DS. Estimation of the concentration of low density lipoprotein cholesterol in plasma without use of the preparative ultracentrifuge. Clin Chem. 1972; 18: 499-502.

[30] Araoye MA, Olowoyeye O, The clinical spectrum of Hypertensive Heart Failure: A Point Score System for solving an old problem. E Afri Med J 1984; 61 (4): 306-315.

[31] Keith NM, Wagener HP, Barker NW. Some different types of essential hypertension: their course and prognosis. Am J Med Sci 1939; 197: 332-343.

[32] Araoye M. A. Left Ventricular Hypertrophy by Electrocardiogram. A code system applicable to Negroes. Nig Postgrad Med J.1996; 3:92-97.
[33] Araoye M. A. Left Ventricular Hypertrophy by Electrocardiogram. Letter to the Editor, Nig Postgrad Med J. 1999; 6: 189.

[34] Macruz R, Perloff JK, Case RB. A method for the electrocardiographic recognition of atrial enlargement. Circulation 1958; 17:882-889.

[35] Murugan PR, Padmacathi T. A study of prevalence of Hyperuricemia in hypertension. International Journal Of Recent Scientific Research 2015; 6(7): 5257-59.

[36] Puig J. G., Torres R, Ruilope L. M AT1 blockers and uric acid metabolism: are there relevant differences? Hypertens 2002; 20(S5); 529-32.

[37] Francesca S. Stefano P. Giovanni T et al. Serum uric acid and related factors in 500 hospitalized subjects. Metal 1996; 45 (12): 1557-1561.

[38] Johnson RJ, Kang DH, Feig D, Kivlighn S, Kanellis J, Watanabe $\mathrm{S}$, et al. Is there a pathogenetic role for uric acid in hypertension and cardiovascular and renal disease? Hypertension 2003; 41(6):1183-1190.

[39] Mene P, Punzo G. Uric acid: bystander or culprit in hypertension and progressive renal disease? Journal of Hypertension 2008; 26(11):2085-2092.

[40] Khosla UM, Zharikov S, Finch JL, Nakagawa T, Roncal C, $\mathrm{Mu} \mathrm{W}$, et al. Hyperuricemia induces endothelial dysfunction. Kidney International 2005; 67(5):1739-1742.

[41] Farquharson CA, Butler R, Hill A, Belch JJ, Struthers AD. Allopurinol improves endothelial dysfunction in chronic heart failure. Circulation 2002; 106(2):221-226.

[42] Doehner W, Schoene N, Rauchhaus M, Leyva-Leon F, Pavitt DV, Reaveley DA, et al. Effects of xanthine oxidase inhibition with allopurinol on endothelial function and peripheral blood flow in hyperuricemic patients with chronic heart failure: results from 2 placebo-controlled studies. Circulation 2002; 105 (22): 2619-2624.

[43] Mazzali M, Kanellis J, Han L, Feng L, Xia YY, Chen Q, et al. Hyperuricemia induces a primary renal arteriolopathy in rats by a blood pressure-independent mechanism. American Journal of Physiology 2002; 282(6 51-6): F991F997.

[44] Rao GN, Corson MA, Berk BC. Uric acid stimulates vascular smooth muscle cell proliferation by increasing platelet-derived growth factor A-chain expression. J Biol Chem. 1991; 266(13):8604-8608.

[45] Perlstein TS, Gumieniak O, Hopkins PN, Murphey LJ, Brown NJ, Williams GH, et al. Uric acid and the state of the intrarenal renin-angiotensin system in humans. Kidney International 2004; 66(4): 1465-1470.

[46] Toma I, Kan J, Meer E, Pet-Peterdi J. Uric acid triggers renin release via a macula densa-dependent pathway. Presented at: American Society of Nephrology Annual Meeting; San Francisco, CA. 2007. F-P0240.

[47] Ruilope L. M., Garcia - Puig J. Hyperuricemia and renal function. Curr Hypertens Rep. 2001; 197-202.

[48] Viazzi F, Parodi D, Leoncini G et al. Serum uric acid and target organ damage in primary hypertension. Hypertension 2005; 45: 991-6. 
[49] Lorenz CH, Walker ES, Morgan VL et al. Normal human right and left ventricular mass, systolic function and gender differences by cine magnetic resonance imaging. J Cardiovasc Magn Reson. 1999; 1(1):7-21.

[50] Sandstede J, Lipke C, Beer M et al. Age and gender specific differences in left and right ventricular cardiac function and mass determined by cine magnetic resonance imaging. European Radiology 2000; 10 (3):438 - 42.

[51] Giuseppe M, Giovanni C. The metabolic syndrome and its relationship to hypertensive target organ damage. Clin Hypertens 2006; 8:195-201.

[52] Mule G, Nardi E, Cottone S et al. Influence of metabolic syndrome on hypertension - related target organ damage. J. Intern. Med. 2005; 257: 503-13.

[53] Raeven GM. Banting lecture 1988. Role of insulin resistance in human diseases. Diabetes 1988; 37:1595-1607.

[54] Kaplan NM. The deadly quartet: Upper body adiposity, glucose intolerance, hypertriglyceridemia and hypertension. Arch Intern Med. 1989; 149:1514-20.

[55] Straus DS. Growth -stimulatory actions of insulin in vitro and in vivo. Endocr Rev. 1984; 5: 356-69.

[56] Andronico G, Wangano MT, Mule G. et al. Insulin-like growth factor 1 and sodium-lithium counter transport in essential hypertension and in hypertensive left ventricular hypertrophy. Hypertens 1993; 11: 1097-101.

[57] Schlaich MP, Kaye DM, Lambert E et al. Relation between cardiac sympathetic activity and hypertensive left ventricular hypertrophy. Circulation 2003; 108: 560-65. 